\title{
Is there any association between hormonal contraceptives and cervical neoplasia in a poor Nigerian setting?
}

This article was published in the following Dove Press journal:

OncoTargets and Therapy

27 July 2015

Number of times this article has been viewed

\author{
Leonard Ogbonna Ajah ${ }^{1,2}$ \\ Chibuike Ogwuegbu \\ Chigbu $^{2}$ \\ Benjamin Chukwuma \\ Ozumba ${ }^{2}$ \\ Theophilus Chimezie \\ Oguanuo ${ }^{2}$ \\ Paul Olisaemeka Ezeonu' \\ 'Department of Obstetrics and \\ Gynaecology, Federal Teaching \\ Hospital, Abakaliki, Nigeria; \\ ${ }^{2}$ Department of Obstetrics and \\ Gynaecology, University of Nigeria \\ Teaching Hospital, Enugu, Nigeria
}

Correspondence: Leonard Ogbonna Ajah Department of Obstetrics and Gynaecology, Federal Teaching Hospital, P.M.B I02, Abakaliki, Ebonyi, Nigeria

Tel +234803 3920789

Email leookpanku@yahoo.com
Background: The association between hormonal contraception and cervical cancer is controversial. These controversies may hamper the uptake of hormonal contraceptives.

Objective: To determine the association between hormonal contraceptives and cervical neoplasia.

Materials and methods: This was a case-control study in which Pap-smear results of 156 participants on hormonal contraceptives were compared with those of 156 participants on no form of modern contraception. Modern contraception is defined as the use of such contraceptives as condoms, pills, injectables, intrauterine devices, implants, and female or male sterilization. Those found to have abnormal cervical smear cytology results were subjected further to colposcopy. Biopsy specimens for histology were collected from the participants with obvious cervical lesions or those with suspicious lesions on colposcopy. The results were analyzed with descriptive and inferential statistics at a $95 \%$ level of confidence.

Results: A total of 71 (45.5\%), 60 (38.5\%), and 25 (16.0\%) of the participants on hormonal contraceptives were using oral contraceptives, injectable contraceptives, and implants, respectively. Cervical neoplasia was significantly more common among participants who were $\geq 35$ years old ( $6 \%$ versus $1 \%, P<0.0001)$, rural dwellers ( $6 \%$ versus $3.5 \%, P<0.0001)$, unmarried $(7.6 \%$ versus $3.5 \%, P<0.0001)$, unemployed $(6.8 \%$ versus $3.5 \%, P<0.0001)$, less educated $(6 \%$ versus $3.8 \%, P<0.0001)$, and had high parity $(6.8 \%$ versus $3.6 \%, P<0.0001)$. There was no statistical significant difference in cervical neoplasia between the two groups of participants (7 [4.5\%] versus $6[3.8 \%], P=1.0)$.

Conclusion: There was no association between hormonal contraceptives and cervical neoplasia in this study.

Keywords: hormonal contraceptives, cervical neoplasia, Enugu, Nigeria

\section{Introduction}

Hormonal contraceptives are some of the contraceptive methods used in Nigeria. Many studies have reported that hormonal contraception increases the risk of cervical cancer, as well as being a risk for all stages of cervical cancer especially, in human papilloma virus-positive women. ${ }^{1-4}$ This suggests that oral contraceptives may act as a promoter for papilloma-induced malignancy. ${ }^{1,2}$ However, another study showed a contrary result that there was a weak association between hormonal contraceptives and cervical neoplasia..$^{5}$ The International Agency for Research on Cancer and the International Collaboration of Epidemiological Studies of Cervical Cancer have demonstrated that it is the long-term use of oral contraceptives by women that increases their risk of cervical cancer. ${ }^{6-8}$ However, among the women who stopped taking oral contraceptives, the risk tended to decline after some time and reversed to that of never-users 
after 10 years or more, irrespective of their duration of use of oral contraceptives before stopping. ${ }^{8}$ A study in South Africa reported that prolonged use of oral and injectable hormonal contraceptives was associated with a transiently increased risk of breast and cervical cancer, but with a reduced risk of ovarian and endometrial cancer. However, the observed effects of injectable or oral contraceptives on cancer risk in this study did not appear to differ remarkably. ${ }^{9}$ However, a multinational study conducted in Thailand, Mexico, and Kenya showed a slightly increased risk of premalignant cervical lesion associated with depot medroxyprogesterone acetate, but no increased risk of cervical carcinoma. ${ }^{10}$

Sub-Saharan Africa is still riddled with low contraceptive prevalence, with $10 \%, 39 \%$, and $65 \%$ of reproductive-age women currently using modern contraception in Nigeria, Kenya, and South Africa, respectively. ${ }^{11-13}$ The bulk of the few modern contraceptive methods used in these countries are hormonal contraceptives. ${ }^{10-12}$ Cervical cancer is the commonest cancer of women in sub-Saharan Africa. ${ }^{14}$ The age-standardized incidence rate of cervical cancer per 100,000 women in Africa is 29.3, compared to 11.9 in Europe and 7.7 in North America. ${ }^{15}$ Therefore, these reports on high risk of cervical cancer on women who currently use hormonal contraceptives may further reduce the proportion of women that use modern contraception in Nigeria. There was a paucity of studies on this subject matter in Africa. It was in light of these factors that a study on association between hormonal contraceptives and cervical neoplasia was embarked upon.

\section{Materials and methods Study area}

Enugu State is one of the states in the eastern part of Nigeria. The state shares borders with Abia and Imo states to the south, Ebonyi State to the east, Benue State to the northeast, Kogi State to the northwest, and Anambra State to the west. The state is predominantly rural and agrarian, with a substantial proportion of its working population engaged in farming. It has a population of 3.3 million people according to the 2006 National Population Census, and 17 local government areas. The urban towns are Enugu, Udi, Oji, and Nsukka. ${ }^{16,17}$ Established in 1970, the University of Nigeria Teaching Hospital (UNTH) is the oldest tertiary health care center in eastern Nigeria. It serves as a referral center for the southeastern states of Enugu, Anambra, Abia, Ebonyi, and Imo, the "South-South" states of Delta, Bayelsa, Cross River, Rivers, and Akwa Ibom, as well as the North-Central states of Kogi, Benue, and Nassarawa. Some referrals are also received from
Cameroon. The hospital is a federal tertiary health care institution. The new permanent hospital complex at Ituku-Ozalla is located 21 kilometers from Enugu (the capital of Enugu State), along the Enugu-Port Harcourt Expressway. ${ }^{16}$

\section{Study design}

This study was carried out at the cervical cancer-screening unit of the UNTH, Enugu between October 1, 2012 and December 31, 2013. It was a case-control study in which the consenting women using hormonal contraceptives (oral contraceptive pills, injectable contraceptives, or implants) were recruited from the Family Planning Clinic of UNTH. They constituted the study group. A similar number of women who were not on any form of modern contraception were recruited from the General Outpatient Department and Gynecology Clinic of UNTH, and they constituted the control group. Modern contraception is defined as the use of such contraceptives as condoms, pills, injectables, intrauterine devices, implants, and female or male sterilization. The sampling technique involved systematic random sampling, in which every third client in the attendance register of each of the aforementioned clinics was picked after a random start. Individual counseling was done while the consenting participants were recruited for the study. All participants had Pap-smear cytology. The participants with abnormal cervical smear cytology results further had colposcopy. Biopsy specimens for histology were collected from participants with obvious cervical lesions or those with suspicious lesions under colposcopy. The participants in the two groups were matched for age, parity, and marital status. Age matching was used in a 5-year age grouping: 20-24 years, 25-29 years, 30-34 years, 35-39 years, 40-44 years, and 45-49 years. Matching for parity was also grouped into nulliparity, primiparity, multiparity, and grand multiparity. Marital status was married or unmarried. A structured questionnaire was used to collect biodemographic information from all the participants. Exclusion criteria included pregnancy, women on hormonal contraceptives for less than 1 year, women on dual-contraceptive methods, refusal of consent, and women who had a history suggestive of cervical cancer, such as abnormal vaginal discharge, contact/postcoital bleeding, chronic pelvic pain, and weight loss.

\section{Sample-size calculation}

The minimum sample size for each of the two groups was calculated using the formula: ${ }^{18}$

$$
n=Z^{2}(P)(1-P) / d^{2}
$$


where $\mathrm{n}=$ minimum sample size at the $95 \%$ confidence level; $\mathrm{Z}=$ the standard normal deviation, usually set at 1.96 ; $\mathrm{d}=$ precision: the difference between the true population rate and acceptable sample rate, set at $0.05 ; \mathrm{P}=$ population prevalence from a previous study: ${ }^{19} 4.7 \%$ was used as the prevalence of abnormal cervical epithelial cytology of women using hormonal contraceptives in Mardin city, Turkey. Minimum sample size (n) was calculated thus: $1.96 \times 1.96 \times 0.047 \times(1-0.047) / 0.05 \times 0.05=69$. With the addition of a $20 \%$ attrition rate, the minimal sample size of each of the two groups was 83 .

\section{Data analysis}

Data were analyzed using SPSS version 17 (SPSS Inc., Chicago, IL, USA). McNemar's $\chi^{2}$ for matched-pair studies was used to analyze the categorical data, while
Student's $t$-test was used for continuous variables. $P$-values $\leq 0.05$ were considered statistically significant. Ethical clearance for the study was obtained from the ethics committee of University of Nigeria Teaching Hospital, Enugu.

\section{Results}

A total of 312 women who met the inclusion criteria participated in the study; 156 women were categorized into each of the two groups. The age distribution of the participants was between 20 and 49 years, with a mean age of $37.56 \pm 7.87$ years. Table 1 compares sociodemographic characteristics between women on hormonal contraceptives and nonusers of modern contraception. The age, parity distribution, and marital status of the participants were matched. Moreover, there were no statistically significant differences

Table I Comparison of sociodemographic characteristics among women on hormonal contraceptives and nonusers of modern contraception in Enugu, Nigeria

\begin{tabular}{|c|c|c|c|}
\hline Demographic data & $\begin{array}{l}\text { Participants on hormonal } \\
\text { contraceptives }(n=156), n(\%)\end{array}$ & $\begin{array}{l}\text { Participants on no modern } \\
\text { contraception }(n=156), n(\%)\end{array}$ & $P$-value \\
\hline \multicolumn{4}{|l|}{ Age (years) } \\
\hline $20-24$ & $9(5.8)$ & $9(5.8)$ & $0.95^{*}$ \\
\hline $25-29$ & $23(14.7)$ & $23(14.7)$ & $0.95 *$ \\
\hline $30-34$ & $19(12.2)$ & $19(12.2)$ & $0.95^{*}$ \\
\hline $35-39$ & $35(22.4)$ & $35(22.4)$ & $0.95^{*}$ \\
\hline $40-44$ & $36(23.1)$ & $36(23.1)$ & $0.95 *$ \\
\hline $45-49$ & $34(21.8)$ & $34(21.8)$ & $0.95^{*}$ \\
\hline \multicolumn{4}{|l|}{ Parity } \\
\hline 0 & $7(4.5)$ & $7(4.5)$ & $0.95^{*}$ \\
\hline I & $24(15.4)$ & $24(15.4)$ & $0.95^{*}$ \\
\hline $2-4$ & $63(40.4)$ & $63(40.4)$ & $0.95 *$ \\
\hline$>4$ & $62(39.7)$ & $62(39.7)$ & $0.95^{*}$ \\
\hline \multicolumn{4}{|l|}{ Marital status } \\
\hline Married & $130(83.3)$ & $130(83.3)$ & $0.95 *$ \\
\hline Unmarried & $26(16.7)$ & $26(16.7)$ & $0.95^{*}$ \\
\hline \multicolumn{4}{|l|}{ Occupation } \\
\hline Unemployed & $27(17.3)$ & $30(19.4)$ & 0.73 \\
\hline Teaching & $13(8.3)$ & $10(6.5)$ & 0.82 \\
\hline Civil service & $57(36.5)$ & $50(32.3)$ & 0.50 \\
\hline Trading & $39(25.0)$ & $40(25.8)$ & 0.91 \\
\hline Artisans & $8(5.1)$ & $15(9.7)$ & 0.43 \\
\hline Professionals & $12(7.7)$ & $10(6.5)$ & 0.91 \\
\hline \multicolumn{4}{|l|}{ Education } \\
\hline No formal & $3(2.0)$ & I $(0.65)$ & 0.91 \\
\hline Primary & $30(19.6)$ & I5 (9.7) & 0.11 \\
\hline Secondary & $27(17.6)$ & $44(28.4)$ & 0.05 \\
\hline Tertiary & $96(61.5)$ & $95(61.3)$ & 0.91 \\
\hline \multicolumn{4}{|l|}{ Residence } \\
\hline Rural & $48(30.8)$ & $36(23.1)$ & 0.21 \\
\hline Urban & $108(69.2)$ & $120(76.9)$ & 0.17 \\
\hline $\begin{array}{l}\text { Mean age of first } \\
\text { sexual exposure }\end{array}$ & $18.56 \pm 3.55$ years & $19.20 \pm 2.81$ years & 0.08 \\
\hline
\end{tabular}

Note: *Matched criteria. 
in occupation, educational status, residential address, or mean age of first sexual exposure between the two groups of study participants.

Figure 1 is the pie chart of the proportion of types of hormonal contraceptives used by the participants on hormonal contraceptives. The mean duration of use of the hormonal contraceptives by these participants was $40.19 \pm 17.61$ months. Table 2 summarizes the Pap-smear cytology results between participants on hormonal contraceptives and nonusers of modern contraception. There was no statistically significant difference in abnormal cervical epithelial cytology between the participants on hormonal contraceptives and nonusers of modern contraception.

Table 3 shows the comparison of colposcopy and biopsy result of abnormal Pap-smear cytology between women on hormonal contraceptives and nonusers of modern contraception. There was no statistically significant difference between them. Similarly, there was no statistically significant difference between the two groups of participants in the prevalence of cervical neoplasia. Table 4 shows the risk of demographic variables for cervical neoplasia. Cervical neoplasia was significantly less common among participants who were $\leq 34$ years old, urban dwellers, married, employed, more educated, and had low parity.

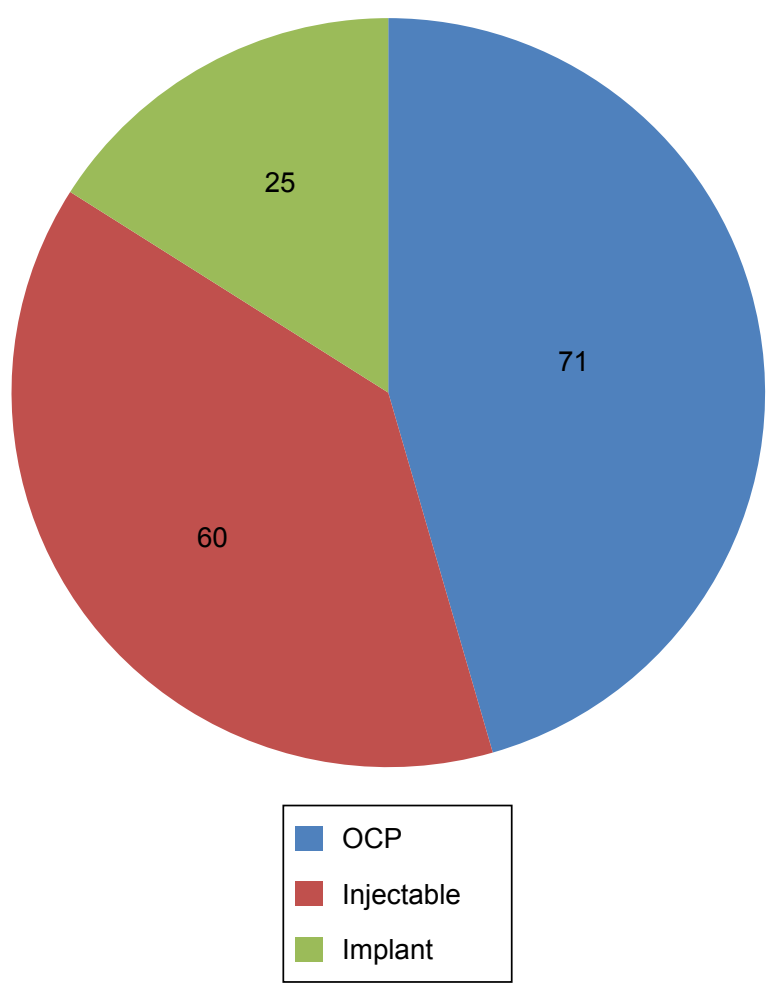

Figure I Pie chart of types of hormonal contraceptives used by the participants on hormonal contraceptives.

Note: Mean duration of use of hormonal contraceptives by the participants on hormonal contraception was $40.19 \pm 17.61$ months.

Abbreviation: OCP, oral contraceptive pill.

Table 2 Pap-smear cytology results of the participants

\begin{tabular}{lll}
\hline Pap-smear result & Frequency $(\mathbf{n}=\mathbf{1 5 6})$ & Percentage \\
\hline Participants on hormonal contraceptives & & 141 \\
$\quad$ Negative to squamous intraepithelial lesion & 15 & 90.4 \\
$\quad$ Low-grade squamous intraepithelial lesion & & 9.6 \\
Participants on no form of modern contraception & 146 & 93.6 \\
$\quad$ Negative to squamous intraepithelial lesion & 2 & 1.3 \\
Atypical squamous cell of undetermined significance & 6 & 3.8 \\
Low-grade squamous intraepithelial lesion & 2 & 1.3 \\
High-grade squamous intraepithelial lesion & & \\
\hline
\end{tabular}

Notes: Totals of $13(9.2 \%)$ and six (4.1\%) negative to squamous intraepithelial lesion among the participants on hormonal contraceptives and those on no form of modern contraception, respectively, were inflammatory cells. Comparison of cervical epithelial abnormalities between the two groups of women (I5 versus ten, $P=0.61)$.

Table 3 Comparison of colposcopy and biopsy results of abnormal Pap smears between women on hormonal contraceptives and those on no form of modern contraception

\begin{tabular}{|c|c|c|c|}
\hline $\begin{array}{l}\text { Colposcopy and } \\
\text { biopsy result }\end{array}$ & $\begin{array}{l}\text { Hormonal contraceptives } \\
(n=156) \text {, frequency }(\%)\end{array}$ & $\begin{array}{l}\text { No modern contraception } \\
(n=156) \text {, frequency }(\%)\end{array}$ & $P$-value \\
\hline Normal & $14(9.0)$ & $7(4.5)$ & 0.46 \\
\hline Inflammation & $7(4.5)$ & $3(1.9)$ & 0.95 \\
\hline CIN I & $6(3.9)$ & $5(3.2)$ & 0.87 \\
\hline CIN II & I (0.6) & I $(0.6)$ & 0.95 \\
\hline
\end{tabular}

Note: Comparison of cervical neoplasia between participants using hormonal contraceptives and nonusers of modern contraception (seven versus six, $P=0.95$ ). Abbreviation: CIN, cervical intraepithelial neoplasia. 
Table 4 Risk of cervical neoplasia based on sociodemographic variables

\begin{tabular}{|c|c|c|c|c|}
\hline \multirow[t]{3}{*}{ Demographic data } & \multicolumn{2}{|c|}{ Cervical (n=3|2) } & \multirow[t]{3}{*}{ OR $(95 \% \mathrm{Cl})$} & \multirow[t]{3}{*}{$P$-value } \\
\hline & \multicolumn{2}{|c|}{ Cervical neoplasia } & & \\
\hline & Yes & No & & \\
\hline \multicolumn{5}{|l|}{ Age (years) } \\
\hline$\leq 34$ & 1 & 101 & $0.568(0.447-0.719)$ & $<0.0001$ \\
\hline$\geq 35$ & 12 & 198 & & \\
\hline \multicolumn{5}{|l|}{ Parity } \\
\hline$\leq 1$ & 2 & 60 & $0.295(0.223-0.385)$ & $<0.0001$ \\
\hline$\geq 2$ & 11 & 239 & & \\
\hline \multicolumn{5}{|l|}{ Marital status } \\
\hline Married & 9 & 251 & $4.474(3.346-6.072)$ & $<0.0001$ \\
\hline Unmarried & 4 & 48 & & \\
\hline \multicolumn{5}{|l|}{ Education } \\
\hline$\leq$ Primary & 3 & 46 & $0.211(0.155-0.282)$ & $<0.0001$ \\
\hline$\geq$ Secondary & 10 & 253 & & \\
\hline \multicolumn{5}{|l|}{ Residence } \\
\hline Rural & 5 & 79 & $0.387(0.298-0.497)$ & $<0.0001$ \\
\hline Urban & 8 & 220 & & \\
\hline \multicolumn{5}{|l|}{ Occupation } \\
\hline Unemployed & 4 & 55 & $0.258(0.193-0.34 I)$ & $<0.0001$ \\
\hline Employed & 9 & 244 & & \\
\hline
\end{tabular}

Abbreviations: $\mathrm{OR}$, odds ratio; $\mathrm{Cl}$, confidence interval.

\section{Discussion}

This study showed that $8.0 \%$ of the women had abnormal cervical cytology, which was similar to the $6.8 \%$ and $7.6 \%$ reported by Pimentel et al and Thomas et al, respectively, in Nigeria. ${ }^{20,21}$ The absence of a significant association between hormonal contraceptives and abnormal cervical epithelial cytology in this study is similar to previous reports from Turkey and Iran. ${ }^{19,22}$ This was also supported by a previous report by Castellsagué and Muñoz. ${ }^{5}$ However, it was contrary to other studies done on the same subject matter. ${ }^{1-4,6,9,10,23}$

Even though there was no statistically significant difference between the participants on hormonal contraceptives and nonusers of modern contraception, for age of first sexual exposure in this study, it appeared that women on modern contraception had the tendency of having earlier sexual exposure than those on no form of modern contraception. Therefore, there is a need to properly educate clients who seek family planning that apart from barrier contraceptives, other modern contraceptive options do not protect against sexually transmitted infections.

Increased prevalence of cervical neoplasia in this study was found among participants with certain sociodemographic characteristics: age $\geq 35$ years, rural dwellers, unmarried, unemployed, less educated, and high parity. This pattern of prevalence was also reported by Bayo et al and Palacio-Mejía et al in Mali and Mexico, respectively. ${ }^{24,25}$ The predominance of cervical neoplasia among this group of women might have been due to prolonged exposure to sexual intercourse and involvement with multiple sexual partners, which are major risk factors for human papilloma virus transmission.

The strength of this study was the systematic sampling and matching of the confounding variables in the recruitment of the study participants. However, it was a hospital-based study, so its findings may not be a true reflection of what is happening in society.

In conclusion, there was no association between hormonal contraceptives and cervical neoplasia. This suggests that hormonal contraceptives may not increase the risk of cervical neoplasia. There is a need to conduct a cohort study on this topic in our environment to further strengthen or refute the safety of hormonal contraceptives.

\section{Disclosure}

The authors report no conflicts of interest in this work.

\section{References}

1. La Vecchia C, Altieri A, Franceschi S, Tavani A. Oral contraceptives and cancer: an update. Drug Saf. 2001;24:741-754.

2. Smith JS, Green J, Berrington de Gonzalez A, et al. Cervical cancer and use of hormonal contraceptives: a systematic review. Lancet. 2003;361: 1159-1167.

3. Epstein RJ. Hormonal contraception and cervical cancer. Lancet. 2003; 361:1915.

4. Thomas DB, Roy RM. Oral contraceptives and invasive adenocarcinoma and adenosquamous carcinoma of the uterine cervix. The World Health Organization Collaborative Study of Neoplasia and Steroid Contraceptives. Am J Epidemiol. 1996;144:281-289. 
5. Castellsagué X, Muñoz N. Chapter 3: Cofactors in human papillomavirus carcinogenesis - role of parity, oral contraceptives, and tobacco smoking. J Natl Cancer Inst Monogr. 2003:20-28.

6. Moreno V, Bosch FX, Muñoz N, et al. Effect of oral contraceptives on risk of cervical cancer in women with human papilloma virus infection: the IARC multicentric case-control study. Lancet. 2002;359:1085-1092.

7. IARC Working Group on the Evaluation of Carcinogenic Risks to Humans. Combined estrogen-progestogen contraceptives and combined estrogen-progestogen menopausal therapy. IARC Monogr Eval Carcinog Risks Hum. 2007;91:1-528.

8. International Collaboration of Epidemiological Studies of Cervical Cancer, Appleby P, Beral V, et al. Cervical cancer and hormonal contraceptives: collaborative reanalysis of individual data for 16,573 women with cervical cancer and 35,509 women without cervical cancer from 24 epidemiological studies. Lancet. 2007;370:1609-1621.

9. Urban M, Banks E, Egger S, et al. Injectable and oral contraceptive use and cancers of the breast, cervix, ovary, and endometrium in black South African women: case-control study. PLoS Med. 2012;9:e1001182.

10. [No authors listed]. Depot medroxyprogesterone acetate (DMPA) and risk of invasive squamous cell cervical cancer. The WHO Collaborative Study of Neoplasia and Steroid Contraceptives. Contraception. 1992; 45:299-312.

11. National Population Commission, ICF Macro. Nigeria Demographic and Health Survey 2008. Abuja: National Population Commission; 2009.

12. Kenya National Bureau of Statistics. Kenya Demographic and Health Survey 2008-2009. Nairobi: KNBS; 2010.

13. Department of Health. South Africa Demographic and Health Survey 2003. Pretoria: Department of Health; 2007.

14. Parkin DM, Ferlay J, Hamdi-Chérif M, et al. Cancer in Africa: Epidemiology and Prevention. Geneva: World Health Organization; 2001.

15. Ferlay J, Bray F, Pisani P, Parkin DM. GLOBOCAN 2002: Cancer Incidence, Mortality and Prevalence Worldwide. Lyon: IARC Cancer Base; 2004.
16. Vamed Engineering. Nigerian teaching hospitals: a federal government health care project [newsletter]. 2007.

17. Williams, L. Nigeria: The Bradt Travel Guide. Chalfont St Peter (UK): Bradt Travel Guides; 2008.

18. Oyejide CO. Health Research Methods for Developing Country Scientists. Ibadan, Nigeria: Codat Publications; 1992.

19. Bariş II, Arman Karakaya Y. Effects of contraception on cervical cytology: data from Mardin City. Turk Patoloji Derg. 2013;29:117-121.

20. Pimentel VM, Jiang X, Mandavilli S, Umenyi Nwana C, Schnatz PF. Prevalence of high-risk cervical human papillomavirus and squamous intraepithelial lesion in Nigeria. J Low Genit Tract Dis. 2013;17: 203-209.

21. Thomas JO, Ojemakinde KO, Ajayi IO, Omigbodun AO, Fawole OI, Oladepo O. Population-based prevalence of abnormal cervical cytology findings and local risk factors in Ibadan, Nigeria: implications for cervical cancer control programs and human papilloma virus immunization. Acta Cytol. 2012;56:251-258.

22. Binesh F, Akhavan A, Pirdehghan A, Davoodi M. Does oral contraceptive pill increase the risk of abnormal Pap smear? Iran J Reprod Med. 2013;11:761-766.

23. Tafurt-Cardona Y, Acosta-Astaiza CP, Sierra-Torres CH. [The prevalence of abnormal cytology and inflammation and their association with risk factors for uterine cervical neoplasms in Cauca, Colombia]. Rev Salud Publica (Bogota). 2012;14:53-66. Spanish.

24. Bayo S, Bosch FX, de Sanjosé S, et al. Risk factors of invasive cervical cancer in Mali. Int J Epidemiol. 2002;31:202-209.

25. Palacio-Mejía LS, Range-Gómez G, Hernández Avila M, LazcanoPonce E. Cervical cancer, a disease of poverty: mortality difference between urban and rural areas in Mexico. Salud Publica Mex. 2003;45 Suppl 3:S315-S325.
OncoTargets and Therapy

\section{Publish your work in this journal}

OncoTargets and Therapy is an international, peer-reviewed, open access journal focusing on the pathological basis of all cancers, potential targets for therapy and treatment protocols employed to improve the management of cancer patients. The journal also focuses on the impact of management programs and new therapeutic agents and protocols on

\section{Dovepress}

patient perspectives such as quality of life, adherence and satisfaction The manuscript management system is completely online and includes a very quick and fair peer-review system, which is all easy to use. Visit http://www.dovepress.com/testimonials.php to read real quotes from published authors. 